\title{
THE DETERMINANTS OF ENTERPRISE PROFITABILITY DURING REDUCED ECONOMIC ACTIVITY
}

\author{
Izabella Steinerowska-Streb \\ Faculty of Management, Department of Economics and Transformation Policy, \\ University of Economics in Katowice, ul. 1 Maja 50, 40-287 Katowice, Poland \\ E-mail: streb@ue.katowice.pl
}

Received 11 July 2011; accepted 09 November 2011

\begin{abstract}
The aim of this study was to identify the characteristic features of small and medium enterprises (SMEs) which contribute to the decrease of profits of those SMEs during a period of reduced economic activity. The investigation was based on a sample of 1107 SMEs functioning in the Polish market. The empirical evidence found the type of manager, market range and legal form as determining factors of SME profits during a period of reduced economic activity. The received results led to the development of a model of firm-specific variables that resul in the decrease of SMEs profits through an economic slowdown.
\end{abstract}

Keywords: small and medium-sized enterprises, small business, profitability, economic slowdown.

Reference to this paper should be made as follows: Steinerowska-Streb, I. 2012. The determinants of enterprise profitability during reduced economic activity, Journal of Business Economics and Management 13(4): 745-762.

JEL Classification: A12, D22, L10.

\section{Introduction}

Small and medium enterprises (SMEs) play an essential role in both developed and developing economies (de Jorge Moreno et al. 2010; Halabi et al. 2010; Zoysa, Hearth 2007). They significantly contribute to the employment, income generation and export revenues as well as being perceived as competition stimulators and a source of innovation (Andersson, Tell 2009; Navickas, Malakauskaite 2009; Jamali et al. 2009; Todorov 2008; Berger, Udell 1998; Eyre and Smallman 1998). However, the importance of SMEs, especially in relation to the job creation, technological advancement, and revenue generation, depends on the performance of each enterprise (Neck 1987; Kotey, Meredith 1997; Wijewardena et al. 2008).

The performance of SMEs is determined by numerous factors that are both internal and external to the enterprise (Zoysa, Hearth 2007). Entrepreneurship literature states that in order to maximize performance, enterprises must accurately match their strategies to their external environment (Tang et al. 2010; Lumpkin, Dess 2001). Such adjust- 
ments are currently very difficult because of the internationalization of economy, the frequent and uncertain changes, the need for continuous innovations, the growing use of information technologies and the increasing competitiveness. Therefore, nowadays enterprises are forced to constantly monitor the market in which they operate and try to utilize changes and overcome emerging constrains.

Enterprises reactions to the environmental changes depend significantly on the internal factors. Some researchers have attempt to identify which of these factors are particularly important for the firms' performance. However, their results vary and the academic jury is still out on this question. A number of relationships have been suggested between performance and the following variables: size, age, location, growth, industry sector/ markets (Smith 1967; Stanworth, Curran 1976; Chell 1985; Keeble et al. 1992; Glancey 1998; Wincent 2005; Camison, Villar-Lopez 2010). Recently, there has been an increase in the investigations into the interactions existing among the profitability of SMEs and owners. These studies/investigations have mainly emphasized that the motivations of professional managers with little or no ownership stake in their firm are contrary to those of the owner-managers; particularly with reference to the impact of mentality, education and goals of the owner-manager on performance was explored (Zoysa, Hearth 2007; Glancey 1998).

Due to the growing role of SMEs on the international markets, researchers have started exploring their performance in the context of internationalization. Studies in this area considered for example whether the international experience is beneficial to small and medium firm performance (Camison, Villar-Lopez 2010).

A number of authors have explored the relationship between performance of SMEs and a number of variables including quality, time, flexibility, finance, customer satisfaction, human resources and gender (Davis et al. 2010; Ha-Brookshire 2009; Zoysa, Hearth 2007; Glancey 1998). Although the accuracy of these measures have been discussed by researchers, there has been no empirical findings suggesting which of the factors are the strongest correlated to the critical dimensions of performance (HaBrookshire 2009).

This paper investigates the financial performance of SMEs which according to Hudson et al. (2001) can be examined by one of the following factors: cash flow, market share, overhead cost reduction, inventory, performance, cost control, sales, profitability, efficiency, product cost reduction. Specifically, total sales and profitability are considered to be key financial performance indicators (O’Cass, Weerawardena 2009). For the purpose of this study profitability was the only factor selected, investigated and described. Profitability was selected as the exposure to decreased profits of particular interest during a time of reduced economic activity. Fall of enterprises' profits is typical for that phase of business cycle. It is mainly a consequence of the reduction of aggregate demand, as well as the changes in others macroeconomic indicators. Contrary, during the period of expansion, business profitability reaches the best levels due to the rapid economic growth.

The survey gathered data from SMEs operating in Poland at least from 2008 till 2010. During that period, the Polish economy was influenced by the financial crisis which 
began with a credit crunch in the US in 2007 (Table 1). While in 2008 GDP reached five percent, in 2009 it decreased to 1.7 percent (Główny Urząd Statystyczny 2010). As a result of reduced economic activity, the financial situation of Polish enterprises got worse and their failure rate considerably increased. The amount of business bankruptcy declared by Polish courts in 2009 raised about 68 percent, comparing to 2008 year (Coface 2011). Then, in the year 2010 the economic situation in the Polish market improved. The GDP reached 3.8 percent (Ministerstwo Rozwoju Regionalnego 2011). The profitability of Polish firms got better and therefore the amount of business bankruptcy decreased. Consequently, data for 2009 were selected for the study.

Table 1. Real GDP Growth per quarter (\% growth $2000=100 \%)$

\begin{tabular}{|c|c|c|c|c|c|c|c|c|c|c|}
\hline \multicolumn{4}{|c|}{2008} & \multicolumn{4}{|c|}{2009} & \multicolumn{3}{|c|}{2010} \\
\hline $\mathrm{I}$ & II & III & IV & I & II & III & IV & I & II & III \\
\hline \multicolumn{11}{|c|}{ change $(\%)$ to the previous quarter } \\
\hline+1.4 & +0.7 & +0.8 & $-0,4$ & +0.4 & +0.6 & +0.4 & $+1,4$ & +0.7 & +1.2 & +1.3 \\
\hline \multicolumn{11}{|c|}{ change $(\%)$ to the same quarter of the previous year } \\
\hline+6.7 & +5.7 & +5.2 & +2.5 & +1.5 & +1.4 & +1.0 & +2.8 & +3.1 & +3.8 & +4.7 \\
\hline
\end{tabular}

Source: Główny Urząd Statystyczny (2010) Produkt krajowy brutto w III kwartale 2010 r. Szacunek wstępny, GUS Departament rachunków narodowych, Warszawa

The study was undertaken to specify the characteristic features of SMEs, which determine their profitability during the market stagnation. It was focused on the relationship between profits and firm size, type of manager (owner or an employee), represented sector, legal form and market range. It was planned to create a model of firm-specific variables resulting in the decrease of SME profits during the period of reduced economic activity.

Although previous studies discussed similar determinants of SMEs profitability, they roughly explored the issue of firm-specific variables with respect to the company profits during the period of reduced economic activity, when companies are at a higher risk of failure. Such an attempt was made in the presented research.

The study addresses four key research questions; all of them relate to a period of reduced economic activity:

1. Are there any characteristic features of firms which determine the profitability of small enterprises?

2. Does the firm size influence the enterprise profitability?

3. Is there any difference in enterprise profitability, whether a firm is run by an owner or by an employed manager?

4. Do small international firms experience lower profit decrease compared with other small enterprises?

The paper is structured in the following way: the next section contains a brief review of the literature developing research aims and hypothesis. The rationale for the study, the sample and the processes of collecting the data are then outlined. In the findings sections, all gathered data are presented and analyzed. The final section concludes the study. 


\section{Hypotheses and conceptual model}

\subsection{Firm size as a determinant of profitability during reduced economic activity}

There are a lot of differences between SMEs and large corporations. SMEs build advantages upon speed, flexibility and niche-filling capabilities. It was also found that smaller firms initiate competitive challenges more aggressively, delivering them faster, and executing them more secretively than larger firms. On the other hand, however, SMEs face specific constraints which set them apart from larger organizations. These constraints include lack of resources and/or knowledge which severely limits decision making in relation to issues such as the selection of products or markets, sustaining long-term growth and optimal structuring of the organization. Moreover, large firms have advantages exerting their bargaining power over suppliers and customers, and compete on broad-based strategies and reputation (Chen, Hambrick 1995).

Taking this diversity into consideration, some differences between smaller and larger firms and profitability are expected. Although researchers explore the moderator effect of the firm size at its profitability, this issue remains unambiguous. The research of US enterprises, made by Ha-Brookshire (2009), revealed that firm size had no statistically significant effect on the profitability. However, previous research by Hansen and Wernerfelt (1989), found a negative effect of the firm size on industry profitability using the data from the US. Meanwhile, Papadogonas (2005) as well as Asimakopoulos et al. (2009), in Greece, found that firm profitability is positively affected by firm size. According to Asimakopoulos et al. (2009) large firms enjoy higher profits compared to small ones. They claim that larger firms take an advantage of their position in negotiating the prices for their inputs and, therefore, they reduce the average costs improving the profitability. It is also suggested that the larger firms better adapt to the new macroeconomic environment and in turn it has a positive effect on their profitability. This evidence conflicts with that described by Glancey (1998), which found that smaller firms in a Scottish sample, are more profitable than larger firms.

It is possible that these research findings investigating the influence of size on the profitability depend on the business cycle. This calls for an important research question regarding whether all sizes of SMEs obtain the same decrease of profits during a time of reduced economic activity. Thus, it is hypothesized that:

H1: During the reduced economic activity, the firm size influence the enterprise profitability. The microenterprises are more exposed to fall of profits than other small firms.

\subsection{The influence of owner-manager versus employed manager on the profitability during the reduced economic activity}

Many researchers suggest that among internal factors that determine the firms' profitability particularly important are management practices of individuals who run the firm (Wijewardena et al. 2008; Andersson, Tell 2009). Moreover, there is a general agreement that other personality characteristics, managerial knowledge, experience, motivation and risk-taking propensity of managers are factors that may have either a positive 
or a negative impact on firm performance (Omerzel, Antoncic 2008; Ackelsberg 1985; Covin, Slevin 1989; Miller, Toulouse 1986; Reijonen, Komppula 2007; Jennings, Beaver 1995; McCartan-Quinn, Carson 2003).

In the case of SMEs the relationships between performance and the person who manages the firm are more complicated than in other organizations. This is because an SMEs may be managed by their owners or by an empolyeed managers. Research investigating this issue frequently emphasize the variable motivations of professional managers with little or no ownership stake in their enterprise in contrast to the motivations of the owner-manager (Glancey 1998).

Their managerial activities may be different, because for employed managers, the firm is only a place of work, whereas for the owner-managers, the enterprise is often a source of autonomy as well as a source of the security to maintain a given lifestyle. In many cases, the firms' profits contributes their whole income. Therefore, the engagement in day-to-day duties of owner-managers may be higher than the engagement of professional managers. That engagement in managerial work is particularly important in SMEs because small firm managers must be able to take on different roles. They often operate different organizational functions, both managerial and operational, depending on what needs to be done and they must switch rapidly between those functions and roles (Floren 2006).

The differences in the managerial activities of manager-owners and employed managers are also a consequence of their competences. Only the owners are able to strategic decision making about the allocation of scarce resources without waiting for the agreement of key decision shareholders. The ownership gives them a control on the whole firms' activity and a powerful influence on the way a firm pursues their objectives. Therefore, the enterprises managed by owners are able to respond quicker and more efficiently to market signals than firms managed by employed workers. They can take more advantages of trade and investment opportunities and reap the benefits of the trading system.

Many studies examined the impact of manager-owners personality attributes, their knowledge and their business strategies on the SME performance (Wijewardena et al. 2008; Reijonen, Komppula 2007; Zoysa, Herath 2006). However, the relation between profitability and the person who runs a small or medium firm in period of reduced economic activity was not thoroughly explored. Taking it into consideration, it seems to be especially important to indentify whether the manager in charge (owner or employed manager) has an impact on the enterprise profitability during a period of reduced economic activity. It is hypothesized that:

H2: SMEs which are managed by owners during a period of reduced economic activity experience a lower profits decrease than SMEs managed by hired managers.

\subsection{A market range as a determinant of SME profitability}

In recent years the globalization, internationalization and quick technology progress caused a lot of changes in the environment of SMEs. Growing competition among local and foreign companies forced many of SMEs to extend their marketplace. Some of them 
have even started running cross-national businesses. Consequently, in recent years an increasing number of SMEs have been involved in the international trade. Thus, SMEs are currently more active in the international markets than in the past (Camison, VillarLopez 2010; Knight 2001).

Due to the expansion of SMEs to the foreign markets, researchers started to explore different aspects of SME's internationalization (O'Cass, Weerawardena 2009; Arslan, Karan 2009; Manolova et al. 2002). O'Cass and Weerawardena (2009) investigated the role of international entrepreneurship and innovation in SME internationalization. The results of this research suggest that international SMEs differ from non-international SMEs in terms of international entrepreneurship, organizational innovation, intensity and firm size.

The research made by Manolova et al. (2002) examined the differences in personal factors between internationalized and non-internationalized small firms comparing the relative importance of four dimensions of human capital: international business skills, international orientation, environmental perceptions and demographic characteristic of firm managers. They found that skills and environmental perceptions were among the most important criteria of successful internationalization.

A lot of studies which explore the cross-national expansion of SMEs are focused on different aspects of performance in the context of internationalization (Camison, VillarLopez 2010; Amal, Freitag Filho 2010; Xie et al. 2009; Bianchi, Ostale 2006; Basly 2007). The evidence shows that success in home countries does not guarantee international success (Bianchi, Ostale 2006). Therefore, researchers investigate which variables determine the performance of international SMEs. Among all identified variables firm size, limited resources, lack of expertise, knowledge, network relationship and technology were found to be important in affecting international performance and success (Camison, Villar-Lopez 2010; Xie et al. 2009; Basly 2007).

The research of Amal and Freitag Filho (2010) suggests that the performance of internationalization depends largely on the ability of companies to remain innovative and facilitate proactive international behavior to learning's process through the maintenance of national and international networking.

As noted, previous research discussed the performance of SMEs in different contexts, however they have not explored, if there is any relationship between the decrease of SMEs profits through the period of reduced economic activity and their international experience. This calls for an important research question exploring whether international SMEs obtain the same decrease in profits during the period of reduced economic activity as non-international SMEs. Thus it is hypothesized that:

H3: Small and medium international firms experience lower profit decrease then noninternational SMEs; during market stagnation.

\subsection{Research model}

Taking into account foregoing sections, this study analyzes the distinctive factors that may influence the profitability of SMEs during reduced economic activity, namely: size, 
the type of manager (owner or employed person), the market range (domestic or cross-country enterprise), represented sector and legal form. To achieve the proposed objectives and prove the proposed hypotheses, the conceptual research model was created. It is depicted by Figure 1.

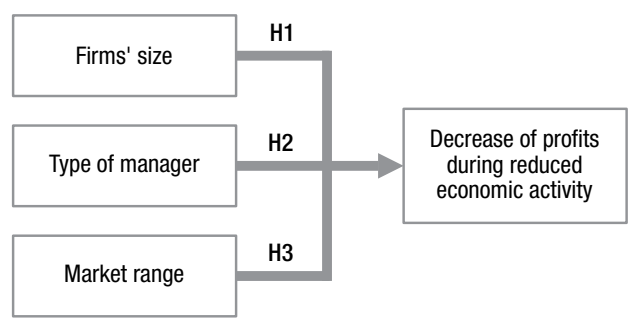

Fig. 1. Research model

\section{Sample and data collection}

The data presented in this study was collected from the primary resources. This research was a part of a larger study exploring the different issues of SMEs. The survey was conducted at the end of 2010 among SMEs enterprises operating in Poland; all data presented here relate to 2009. The term "small and medium enterprises" (SMEs) or "small firms", refers to a business that had less than 250 employees. Within the SME category micro-enterprises, small businesses, and medium enterprises were identified. A medium enterprise is defined as an enterprise which employs no less than 50 persons. A small enterprise is defined as an enterprise which employs fewer than 50 persons. A microenterprise is defined as an enterprise which employs fewer than 10 persons. This classification of small and medium enterprises is based on the European Commission Recommendation, however it uses only the employment criteria instead of a complex of criteria recommended by European Union: employment, turnover, and/or an annual balance sheet, and type of a relationship between enterprise and another firms (European Commission Recommendation of 6 May 2003).

A representative sample was chosen from the e-mail addresses database of Foreign Trade Promotion Group NETEX-STERLING (edition 2010). That database contained the e-mail addresses of 290000 Polish firms.

For the purpose of the study a structured questionnaire was prepared. As a basis for designing this research instrument a detailed review of the literature on SMEs was carried out.

First, the pilot research was conducted. Following this the final questionnaire was prepared. The questionnaire consisted of dichotomous and fixed-alternative questions referring to organizational changes, management methods and other details of business practices. Some of the questions aimed to control the validity of given answers.

The questionnaire was based on a web-site and was accessible only for firms invited to the survey by e-mail. It was addressed to the chief executive of each selected enterprise. A total group of 1238 firms responded to the survey. The overall response rate was 4.9 percent. The energy sector and public institutions were excluded. Finally, a study sample was set at 1107 firms.

A research sample was represented by 58.4 percent of microenterprises; 28.6 percent of small firms and 9 percent of medium enterprises. 24 percent of the research sample 
represented the trade sector, 21.4 percent - production, 38.1 percent - service (including construction companies), and remaining 16.5 percent of enterprises - mixed activity.

The majority of surveyed firms were operating in a domestic market (48.19 percent). The dominant legal form among surveyed enterprises was a sole proprietorship (56.55 percent). 21.95 percent of responding firms were functioning as a limited liability companies and joint stock companies. The rest 21.95 percent of responding group represented other partnerships.

Almost 90 percent of responding enterprises were managed by manager-owners. An owner-manager was defined as someone who founded or acquired a small firm for personal goals and for whom the firm is typically the primary source of income (Mazzarol et al. 2009). He/she plays the main role in the decision making process and sets firms strategy. In most cases, the firm is inseparable from the owner-manager (Mazzarol et al. 2009; Glancey 1998). Meanwhile, hired manager was treated as a person who is employed to manage the firm instead of the owner. He or she focuses on the firm management, and uses the knowledge to achieve assumed firms' goals.

The statistical analysis was calculated based on STATISTICA 9.0 software (StatSoft Inc.). Descriptive statistics were used to show gathered data. The differences in selected key characteristic features of small businesses which could determine the enterprise's profitability during the period of reduced economic activity, were analyzed by $X^{2}$ Pearsona Test. The significant $p$-level was set below 0.05 .

The variables, for which the $X^{2}$ test resulted in significant differences, were then used in data mining analysis. To limit the number of factors included in the model, a regression and classification analyses were used. Next, the variables which remained to have a significant influence were involved in creation of classification tree. Then, positive and negative predictive values of obtained model were calculated.

\section{Data analysis and results}

The statistical analysis made by Test $X^{2}$ proved that the type of manager (owner or a hired person) and decrease of enterprise profitability there were statistically significant. When compared the responses to the question regarding the decrease in profits produced by businesses, 492 out of 977 owners and 44 out of 130 professional managers answered positively (Table 2). Such a huge dominance of positive response in a group of owner managed companies, in comparison to firms managed by professional managers, resulted in statistically significant differences $\left(X^{2}=14\right.$ and $\left.p=0.0001\right)$.

Although hypothesis 1 was not proved to be statistically significant, the statistical differences in the responses suggested further analysis was required. The analysis involved two groups of SME factors. First, a general firm characteristics, including sector type, number of employees, legal form or market range; and second, specific managerial features such as scheduling of costs analysis and the proneness to organizational changes. The results of cross-sectional analysis and Pearson $X^{2}$ test for each feature are shown in the Table 3. 
Table 2. Decrease of profits in 2009 by type of manager

\begin{tabular}{lccc}
\hline \multicolumn{1}{c}{ Manager type } & Decrease of profits & No decrease of profits & Total in raw \\
\hline Number of owner & 492 & 485 & 977 \\
Managed Business & & & \\
Percent in columns & $91.80 \%$ & $84.94 \%$ & \\
Percent in rows & $50.36 \%$ & $49.64 \%$ & $88.25 \%$ \\
Percent of total & $44.44 \%$ & $43.81 \%$ & 130 \\
\hline Number of business & 44 & 86 & \\
Managed by Hired & & & \\
Managers & & $15.06 \%$ & \\
Percent in columns & $8.20 \%$ & $66.15 \%$ & $11.75 \%$ \\
Percent in rows & $33.85 \%$ & $7.78 \%$ & 1107 \\
Percent of total & $3.97 \%$ & 571 & \\
\hline Total of group & 536 & $51.58 \%$ & \\
Cumulative percent & $48.42 \%$ & & \\
\hline
\end{tabular}

Table 3. Cross-sectional analysis and the results of Pearson $X^{2}$ test for the research sample

\begin{tabular}{|c|c|c|c|c|c|c|}
\hline & \multirow[b]{2}{*}{ Variable } & \multicolumn{2}{|c|}{$\begin{array}{c}\text { Owner Managed } \\
\text { Business }\end{array}$} & \multicolumn{2}{|c|}{$\begin{array}{l}\text { Business Managed } \\
\text { by Hired Managers }\end{array}$} & \multirow{2}{*}{$X^{2} / p$} \\
\hline & & count & percent & count & percent & \\
\hline & 1 & 2 & 3 & 4 & 5 & 6 \\
\hline \multirow{4}{*}{$\begin{array}{l}\text { Costs } \\
\text { Analysis }\end{array}$} & Regular & 558 & 56 & 105 & 80.8 & \multirow{4}{*}{$\begin{aligned} X^{2} & =30.79 \\
P & <0.01\end{aligned}$} \\
\hline & Only during the crisis & 95 & 9.5 & 7 & 5.3 & \\
\hline & Rarely & 291 & 29.2 & 17 & 13.1 & \\
\hline & None & 33 & 3.3 & 1 & 0.8 & \\
\hline \multirow{4}{*}{$\begin{array}{l}\text { Represen- } \\
\text { ted Sector }\end{array}$} & Trade & 214 & 21.9 & 36 & 27.7 & \multirow{4}{*}{$\begin{array}{c}X^{2}=4.17 \\
P=0.22\end{array}$} \\
\hline & Production & 227 & 23.2 & 34 & 26.1 & \\
\hline & Mixed activity & 158 & 16.2 & 21 & 16.2 & \\
\hline & $\begin{array}{l}\text { Services and construction } \\
\text { sector }\end{array}$ & 378 & 38.7 & 39 & 30 & \\
\hline \multirow{3}{*}{$\begin{array}{l}\text { Organiza- } \\
\text { tional } \\
\text { Changes }\end{array}$} & Often & 547 & 56 & 76 & 58.5 & \multirow{3}{*}{$\begin{array}{c}X^{2}=0.78 \\
P=0.68\end{array}$} \\
\hline & Rarely & 349 & 35.7 & 46 & 35.3 & \\
\hline & Never & 81 & 8.3 & 8 & 6.2 & \\
\hline \multirow{5}{*}{$\begin{array}{l}\text { Number of } \\
\text { Employees }\end{array}$} & 0 & 104 & 10.6 & 1 & 0.8 & \multirow{5}{*}{$\begin{array}{c}X^{2}=111.37 \\
P<0.01\end{array}$} \\
\hline & $1-5$ & 363 & 37.2 & 19 & 14.6 & \\
\hline & $6-10$ & 187 & 19.2 & 17 & 13.1 & \\
\hline & $11-50$ & 262 & 26.8 & 54 & 41.5 & \\
\hline & $51-250$ & 61 & 6.2 & 39 & 30 & \\
\hline
\end{tabular}


End of Table 3

\begin{tabular}{|c|c|c|c|c|c|c|}
\hline & 1 & 2 & 3 & 4 & 5 & 6 \\
\hline \multirow{3}{*}{$\begin{array}{l}\text { Market } \\
\text { Range }\end{array}$} & Local & 326 & 33.4 & 29 & 22.3 & \multirow{3}{*}{$\begin{array}{l}X^{2}=10.29 \\
P=0.0058\end{array}$} \\
\hline & Domestic & 471 & 48.2 & 64 & 49.2 & \\
\hline & International & 180 & 18.4 & 37 & 28.5 & \\
\hline \multirow{3}{*}{$\begin{array}{l}\text { Legal } \\
\text { Form }\end{array}$} & Sole proprietorship & 602 & 61.6 & 27 & 20.8 & \multirow{3}{*}{$\begin{aligned} X^{2} & =220.5 \\
P & <0.01\end{aligned}$} \\
\hline & $\begin{array}{l}\text { Limited liability company } \\
\text { and Joint stock company }\end{array}$ & 149 & 15.3 & 94 & 72.3 & \\
\hline & Other partnerships & 226 & 23.1 & 9 & 6.9 & \\
\hline
\end{tabular}

Statistically, the strongest differences between those groups were found in case of the legal form of the company and the number of employees. Also cost analysis and market range were statistically different in the case of owner managed companies and firms managed by an employed manager. No such differences were present for branch of the represented sector and organizational changes.

The next step of the analysis was aimed to choose the best predictors of company profitability during the period of reduced economic activity. Before the classification and regression tree (CR\&T) was built, the selection of the most powerful predictors was completed. This was based on data mining analysis. Calculated $X^{2}$ and significance level $p$ are shown in Table 4. This process enabled to reduce the number of variables to type of management, sole proprietorship, number of employees, and market range. Finally, the data mining analysis resulted in formation of classification and regression tree, which is presented in Figure 2. The classification matrix for that CR\&T presented in Table 6 shows that 370 out of 536 firms which had a fall in profits can be identified (positive predictive value 69.03 percent). However, the predictive negative value of this model was only 43.26 percent (Table 5).

Table 4. $X^{2}$ and significance level $p$ of the predictors of company profitability during the period of reduced economic activity

\begin{tabular}{lcc}
\hline \multicolumn{1}{c}{ Factor - profitability predictor } & $X^{2}$ & $p$ \\
\hline Type of Manager & 12.52531 & 0.000401 \\
\hline Sole Proprietorship & 9.32534 & 0.025264 \\
\hline Number of Employees & 8.93143 & 0.062837 \\
\hline Market Range & 8.07560 & 0.017636 \\
\hline Costs Analysis & 5.33604 & 0.148781 \\
\hline Organizational Changes & 3.52349 & 0.171745 \\
\hline
\end{tabular}




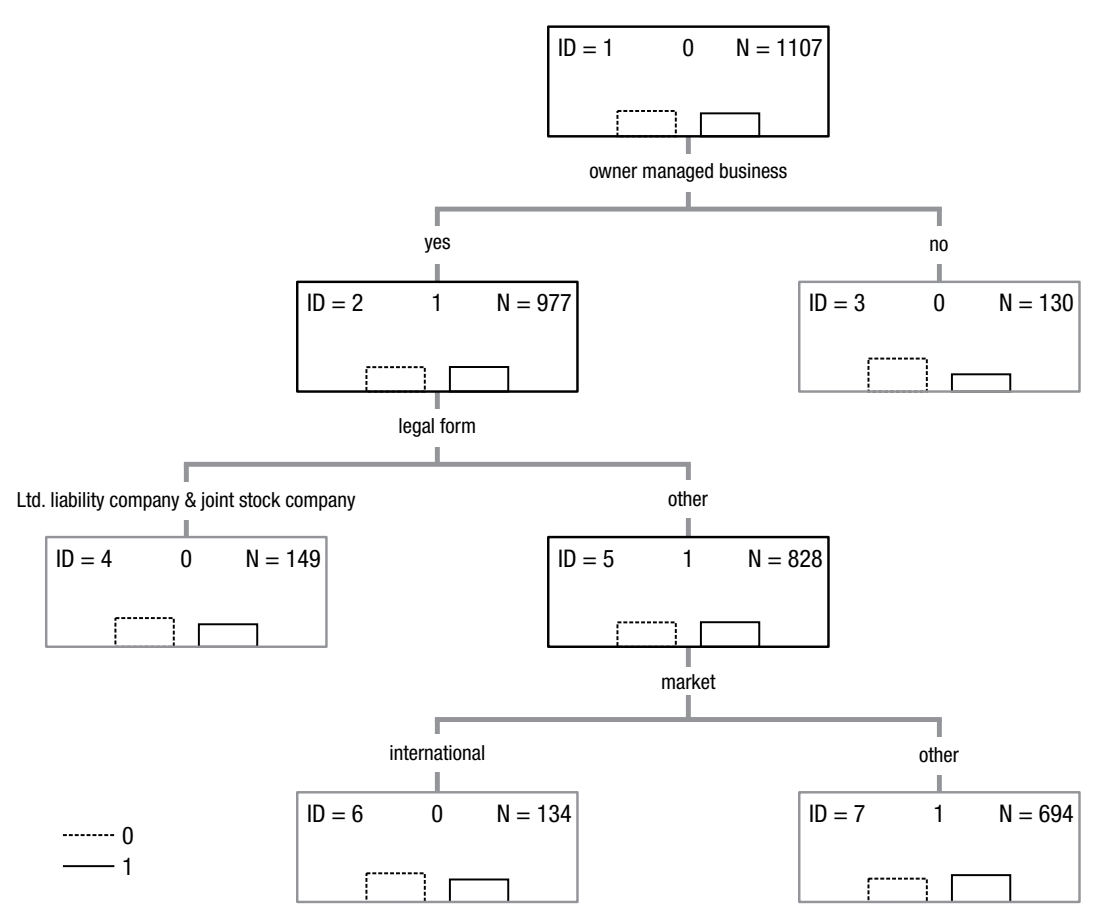

Fig. 2. Classification and regression tree for fall in profits number of shared hiches: 3 , number of final hiches: 4

Table 5. Predictive value for the regression tree (for the model of firm-specific variables resulting in the decrease of SME profits during the period of reduced economic activity)

\begin{tabular}{|c|c|c|c|c|}
\hline & Observed & Predicted 0 & Predicted 1 & Total in raw \\
\hline Number & \multirow{4}{*}{0} & 247 & 324 & 571 \\
\hline Percent in columns & & $59.81 \%$ & $46.69 \%$ & \\
\hline Percent in rows & & $43.26 \%$ & $56.74 \%$ & \\
\hline Percent of total & & $22.31 \%$ & $29.27 \%$ & $51.58 \%$ \\
\hline Number & \multirow{4}{*}{1} & 166 & 370 & 536 \\
\hline Percent in columns & & $40.19 \%$ & $53.31 \%$ & \\
\hline Percent in rows & & $30.97 \%$ & $69.03 \%$ & \\
\hline Percent of total & & $15.00 \%$ & $33.42 \%$ & $48.42 \%$ \\
\hline Number & Total of group & 413 & 694 & 1107 \\
\hline Cumulative percent & & $37.31 \%$ & $62.69 \%$ & \\
\hline
\end{tabular}


Table 6. Predictive value of regression tree

\begin{tabular}{lcccc}
\hline & Observed & Predicted 0 & Predicted 1 & Total in raw \\
\hline Number & & 247 & 324 & 571 \\
Percent in columns & 0 & $59.81 \%$ & $46.69 \%$ & \\
Percent in rows & & $43.26 \%$ & $56.74 \%$ & \\
Percent of total & & $22.31 \%$ & $29.27 \%$ & $51.58 \%$ \\
\hline Number & 1 & $40.19 \%$ & $53.31 \%$ & 536 \\
Percent in columns & & $30.97 \%$ & $69.03 \%$ & \\
Percent in rows & & $15.00 \%$ & $33.42 \%$ & $48.42 \%$ \\
Percent of total & \multirow{2}{*}{ Total of group } & 413 & 694 & 1107 \\
Number & & $37.31 \%$ & $62.69 \%$ & \\
Cumulative percent & & &
\end{tabular}

\section{Discussion and conclusions}

Although the effects of firm characteristics features on firm performance have gained some attention, studies describing the impact of key characteristic features of small firms on enterprise profitability during reduced economic activity have not been fully explored. The objective of this research was to highlight the importance of firm-specific variables in enterprise profitability during a period of reduced economic activity. Specifically, the firm size (measured by an amount of employees), the type of manager (owner or employed person), market range (domestic or cross-country enterprise) represented sector and legal form were studied.

Empirical evidence finds the type of manager as a determining factor of a firm profits. Analysed results suggest that if SMEs are managed by the owner, then they are more exposed to the decrease of profits during reduced economic activity, than if they are managed by an employed manager. That is, when the management procedures are made by a hired, professional manager, the possibility for the drop off profits caused by market depression is lower, than when firm is run by the owner.

Contrary to the expectations, the hypothesized positive influence of the owner for firms' profits during the time of reduced economic activity, turned out to be incorrect. The statistical analysis proved that SMEs managed by employed managers experience lower profit decreases while the market is in stagnation. These results may be explained by previous studies, which investigated the variables influencing the financial profitability of SMEs as well as the issue of SMEs failure. Among all explored internal factors, the competences and other personality characteristics of those who manage the enterprise are universally regarded as one of the most powerful set of factors having either positive or negative impact on its financial performance and ultimate success (Wijewardena et al. 2008; Kotey, Meredith 1997). Moreover, there is a dependence between the entrepreneur's education and the firm's survival rate (Parker, van Praag 2004). Taking this into consideration, it seems highly probable, that managerial competencies of SMEs owner-managers from the present research, were not enough while market fluctuations. However, such results still seem to be surprising, because Polish entrepreneurs have 
generally entrepreneurial mentality and their educational level is high (Daszkiewicz 2004; Dąbek 2002; Sibińska 2001). Therefore, one could expect that those attributes of Polish entrepreneurs should positively impact on the firms profitability during market stagnation. Nevertheless, the present research had not confirmed such a statement.

It is important to note that the education of Polish entrepreneurs is mostly technical, not economic (Daszkiewicz 2004; Sibińska 2001). Meanwhile, understanding of technical aspects of the industry is important for managers (Martin, Staines 1994), but it can be insufficient to face up the managers' duties during the reduced economic activity. Thus, lack of sufficient economical education could impact the research findings.

The statistical analysis of the present study found also that SMEs which were run by the owner, experienced a lower profit decrease during a period of reduced economic activity, when their legal form was either limited liability company (LLC) or joint stock company (JSC), rather than other legal forms of firms. This may be caused by better access of LLC and JSC to the financial resources, which were not available for the remaining partnerships as well as for the sole proprietorships. Due to the entire accessible capital, these entities may have greater possibility to introduce all needed organizational changes and better adjustments to the market fluctuations. For that reason, LLC and JSC could experience lower profits decrease than others firms, within a market depression. Such a result contributes to the literature exploring the issue of survival rate of SMEs. Findings confirm research results of Wilmańska (2010) indicating that the survival rate is higher for SMEs which are functioning as LLC or JSC, rather than other legal forms of enterprises. Accordingly, the present study suggests that enterprises organized as LLC or JSC have better survival rate and are less exposed to the profits reduction during the period of reduced economic activity.

In addition, the present research suggests that SMEs, which are run by the owner, and are LLC or JSC, experience lower profit decrease during market stagnation when they have an international market range. Such a result may be explained by risk diversification among the countries in which these enterprises offer their products. However, it is also probable that a smaller decrease of profits in international SMEs is the effect of more effective organization and more entrepreneurial nature of those enterprises, than non-international small businesses. This statement can be supported by a study conducted by O'Cass and Weerawardena (2009) which examined the role of international entrepreneurship and innovation in SMEs. It suggests that international SMEs differ from non-international SMEs in terms of international entrepreneurship, organizational innovation intensity and market performance. Exporters relative to non-exporters are more likely to develop superior products and perceive or explore more innovative ways of performing the value-creating activities. Thus, the entrepreneurial nature of international SMEs can help them to better adjust to the market fluctuations and in this way influence the profitability of these entities.

This result contributes also to the previous research indicating that internationalization has a positive relationship with the performance of small businesses. The study of Baird et al. (1994) showed that SMEs can increase their return on sales by taking their current 
products into foreign markets either on their own or through foreign alliances. Similarly, the findings of Chelliah et al. (2010) indicate that internationalization can improve performance and motivate firms to continuously capture foreign markets. Accordingly, the present study confirms earlier research about positive relationships between internationalization and performance. The current study measures performance of SMEs by the profitability. It finds that a lower profits decrease of small businesses during a period of reduced economic activity occur when the SMEs has an international market range and are run by the owner, as well as not being LLC or JSC.

Finally, it can be concluded, that the characteristic features of a firm that determine the profitability of small enterprises during reduced economic activity are: the type of manager, market range and legal form. Hypotheses $\mathrm{H} 1$ and $\mathrm{H} 2$ are rejected and $\mathrm{H} 3$ is confirmed.

Knowledge about these factors can be vital for SMEs owners, because they are forced to accept market fluctuations running their businesses independently of market conditions. Awareness of that issue is also significant for SMEs policies. Information about factors influencing SMEs profits can help policymakers to undertake proper decisions during reduced economic activity.

Understanding of the determinants of enterprise profitability during the reduced economic activity should be extended. The present survey has a few limitations. First, it was made only on a sample of Polish enterprises. It should emphasized, that Poland belongs to post-communist countries which began the transformation to the market economy just about twenty years ago. Some professionals highlight that the transformation in Poland is still lasting and it will go on for a long time. As G. Kołodko states, that process will proceed for at least two generations. He suggests that the final effect of transformation should be based on the estimation of the dynamism and the balance of economic processes as well as on the effectiveness of the market mechanism (Kołodko 2009). However, there are also experts claiming that the transformation in Eastern European countries which have already joined the European Union (Bulgaria, Czech Republic, Estonia, Lithuania, Latvia, Poland, Romania, Slovakia, Slovenia, Hungary) was successfully completed. They maintain that those states completely changed their institutional structure and that they entirely adopted the roles of the market economy.

Taking into consideration that Poland is a transitional economy, comparative research in other countries might complete would be needed to validate these results in a wider context. Therefore, the conclusions of the analysis should be interpreted with caution. A comparative research in other, not transitional countries might complete its results.

Finally, the investigation was only conducted during relatively short period when considering the business cycle. Perhaps, the same study conducted in a longer period might have influenced the results. Therefore, this topic should be the subject of further direct empirical testing. 


\section{References}

Ackelsberg, R. 1985. Small businesses do plan and it pays off, Long Range Planning 18(5): 61-67. http://dx.doi.org/10.1016/0024-6301(85)90202-X

Amal, M.; Freitag Filho, A. R. 2010. Internationalization of small- and medium-sized enterprises: a multi case study, European Business Review 22(6): 608-623.

http://dx.doi.org/10.1108/09555341011082916

Andersson, S.; Tell, J. 2009. The relationship between the manager and growth in small firms, Journal of Small Business and Enterprise Management 16(4): 568.

Arslan, O.; Karan, M. B. 2009. Credit risks and internationalization of SMEs, Journal of Business Economics and Management 10(4): 361-368. http://dx.doi.org/10.3846/1611-1699.2009.10.361-368 Asimakopoulos, I.; Samitas, A.; Papadogonas, T. 2009. Firm-specific and economy wide determinants of firm profitability Greek evidence using panel data, Managerial Finance 35(11): 930-939. http://dx.doi.org/10.1108/03074350910993818

Baird, I. S.; Lyles, M. A.; Orris, J. B. 1994. The choice of international strategies by small businesses, Journal of Small Business Management 32(1): 48-59.

Basly, S. 2007. The internationalization of family SME an organizational learning and knowledge development perspective, Baltic Journal of Management 2(2): 154-180.

http://dx.doi.org/10.1108/17465260710750973

Berger, A.; Udell, G. 1998. The economics of small business finance: the roles of private equity and debt markets in financial growth cycle, Journal of Banking and Finance 22: 613-673.

http://dx.doi.org/10.1016/S0378-4266(98)00038-7

Bianchi, C. C.; Ostale, E. 2006. Lessons learned from unsuccessful internationalization attempts: examples of multinational retails in Chile, Journal of Business Research 59: 140-147.

http://dx.doi.org/10.1016/j.jbusres.2005.01.002

Camison, C.; Villar-Lopez, A. 2010. Effect of SME's international experience on foreign intensity and economic performance: the mediating role of internationally exploitable assets and competitive strategy, Journal of Small Business Management 48(2): 116-151.

http://dx.doi.org/10.1111/j.1540-627X.2010.00289.x

Chell, E. 1985. The entrepreneurial personality: a few ghosts laid to rest, International Small Business Journal 3(3): 43-54. http://dx.doi.org/10.1177/026624268500300303

Chelliah, S.; Sulaiman, M.; Yusoff, Y. M. 2010. Internationalization and performance: small and medium enterprises (SMEs) in Malaysia, International Journal of Business and Management 5(6): 27-37.

Chen, M.; Hambrick, D. C. 1995. Speed, stealth, and selective attack: how small firms differ from large firms in competitive behavior, Academy of Marketing Management Journal 38: 453-482.

Chu, W. 2009. The influence of family ownership on SME performance: evidence from public firms in Taiwan, Small Business Economics 33(3): 353-373.

http://dx.doi.org/10.1007/s11187-009-9178-6

Coface. 2011. Raport Coface nt. Upadtości firm w Polsce w 2010 roku [cited 20 November 2011]. Coface Poland, Warsaw, Poland. Available from Internet: www.coface.pl

Covin, J. G.; Slevin, D. P. 1989. Strategic management of small firms in hostile and benign environments, Strategic Management Journal 10: 75-87. http://dx.doi.org/10.1002/smj.4250100107

Dąbek, M. 2002. Menedżerowie okresu transformacji. Problemy, potencjat, rozwój. Wydawnictwo Uniwersytetu Wrocławskiego, Wrocław, Poland.

Daszkiewicz, N. 2004. Internacjonalizacja małych i średnich przedsiębiorstw we współczesnej gospodarce. SPG, Gdańsk, Poland. 
Davies, J.; Hides, M.; Powell, M. 2002. Defining the development needs of entrepreneurs in SMEs, Education + Training 44(8/9): 406-412.

Davis, P.; Babakus, E.; Danskin, E.; Pett, T. 2010. The influence of CEO gender on market orientation and performance in service small and medium-sized service businesses, Journal of Small Business Management 48(4): 475-496. http://dx.doi.org/10.1111/j.1540-627X.2010.00305.x

de Jorge Moreno, J.; Castillo, L. L.; de Zuzani Masere, E. 2010. Firm size and entrepreneurial characteristics: evidence from the SME sector in Argentina, Journal of Business Economics and Management 11(2): 259-282. http://dx.doi.org/10.3846/jbem.2010.13

European Commission 2003. European Commission Recommendation of 6 May 2003 concerning the definition of micro, small and medium-sized enterprises. Document number C (2003) 1422, Text with EEA relevance, 2003/361/EC, Official Journal of the European Union 124: 36.

Eyre, P.; Smallman, C. 1998. Euromanagement competences in small- and medium-sized enterprises: a development path for the new millennium?, Management Decision 36/1: 34-42.

http://dx.doi.org/10.1108/00251749810199239

Floren, H. 2006. Managerial work in small firms: summarising what we know and sketching a research agenda, International Journal of Entrepreneurial Behaviour \& Research 12(5): 272-288. http://dx.doi.org/10.1108/13552550610687646

Glancey, K. 1998. Determinants of growth and profitability in small entrepreneurial firms, International of Entrepreneurial Behaviour \& Research 4(1): 18-27.

Ha-Brookshire, J. E. 2009. Does the firm size matter on firm entrepreneurship and performance? US apparel import intermediary case, Journal of Small Business and Enterprise Development 16(1): 131-145. http://dx.doi.org/10.1108/14626000910932926

Halabi, A. K.; Barrett, R.; Dyt, R. 2010. Understanding financial information used to assess small firm performance an Australian qualitative study, Qualitative Research in Accounting \& Management 7(2): 163. http://dx.doi.org/10.1108/11766091011050840

Hansen, G. S.; Wernerfelt, B. 1989. Determinants of firm performance: the relative importance of economic and organizational factors, Strategic Management Journal 10: 399-411.

http://dx.doi.org/10.1002/smj.4250100502

Hudson, M.; Smart, A.; Bourne, M. 2001. Theory and practice in SME performance measurement systems, International Journal of Operations \& Production Management 21(8): 1102.

http://dx.doi.org/10.1108/EUM0000000005587

Jamali, D.; Zanhour, M.; Keshihian, T. 2009. Peculiar strengthens and relational attributes of SMEs in the context of CRS, Journal of Business Ethics 87: 355-377.

http://dx.doi.org/10.1007/s10551-008-9925-7

Jennings, P. L.; Beaver, G. 1995. The managerial dimension of small business failure, Journal of Strategic Change 4(4) (July-August): 185-200. http://dx.doi.org/10.1002/jsc.4240040402

Keeble, D.; Tyler, P.; Broom, G.; Lewis, J. 1992. Business Success in the Countryside: the Performance of Rural Enterprise. HMSO for DoE, London.

Knight, G. A. 2001. Entrepreneurship and strategy in the international SME, Journal of International Management 7(3): 155-171. http://dx.doi.org/10.1016/S1075-4253(01)00042-4

Kołodko, G. 2009. Wielka Transformacja 1989-2009. Uwarunkowania, przebieg, przyszłość, Ekonomista 3: 175-185.

Kotey, B.; Meredith, G. G. 1997. Relationship among owner/manager personal values and perceptions, business strategies, and enterprise performance, Journal of Small Business Management 35(2): 37-64.

Lumpkin, G. T.; Dess, G. G. 2001. Clarifying the entrepreneurial orientation construct linking it to performance, Academy of Management Review 21(1): 135-172. 
Manolova, T. S.; Brush, C. G.; Edelman, L. F.; Greene, P. G. 2002. Internationalization of small firms: personal factors revisited, International Small Business Journal 20(1): 9-31.

http://dx.doi.org/10.1177/0266242602201003

Martin, G.; Staines, H. 1994. Managerial competences in small firms, Journal of Management Development 13(7): 23-34. http://dx.doi.org/10.1108/02621719410063396

Mazzarol, T.; Reboud, S.; Soutar, G. N. 2009. Strategic planning in growth oriented small firms, International Journal of Entrepreneurial Behaviour \& Research 15(4): 320-321.

http://dx.doi.org/10.1108/13552550910967912

McCartan-Quinn, D.; Carson, D. 2003. Issues which impact upon marketing in the small firm, Small Business Economics 21: 201-213. http://dx.doi.org/10.1023/A:1025070107609

Miller, D.; Toulouse, J. 1986. Strategy, structure, CEO personality and performance in small firms, American Journal of Small Business 10(6): 47-62.

Ministerstwo Rozwoju Regionalnego [Ministry of Regional Development]. 2011. Raport Polska 2011. Gospodarka-Społeczeństwo-Regiony. [Raport Poland 2011. Economy- Society-Regions. Ministerstwo Rozwoju Regionalnego [Ministry of Regional Development]. Warsaw, Poland. Available from Internet: www.mrr.gov.pl

Navickas, V.; Malakauskaite, A. 2009. The impact of clusterization on the development of small and medium-sized enterprise (SME) sector, Journal of Business Economics and Management 10(3): 255-259. http://dx.doi.org/10.3846/1611-1699.2009.10.255-259

Neck, P. A. 1987. Policy issues, in Work Small Enterprises Development: Policies and Programs. $2^{\text {nd }}$. Ed. Neck, P. A.; Nelson, R. E. Management Development Series No. 14. International Labour Office, Geneva.

O'Cass, A.; Weerawardena, J. 2009. Examining the role of international entrepreneurship, innovation and international market performance in SME internationalization, European Journal of Marketing 43(11/12): 1325-1348 http://dx.doi.org/10.1108/03090560910989911

Omerzel, D. G.; Antoncic, B. 2008. Critical entrepreneur knowledge dimensions for the SME performance, Industrial Management \& Data Systems 108(9): 1182-1199.

http://dx.doi.org/10.1108/02635570810914883

Papadogonas, T. 2005. The financial performance of large and small firms: evidence from Greece, International Journal of Financial Services Management 2(1): 14-20.

http://dx.doi.org/10.1504/IJFSM.2007.011668

Parker, S. C.; Van Praag, C. M. 2004. Schooling, capital constraints and entrepreneurial performance: the endogenous triangle, Working Paper 45-04. University of Amsterdam.

Reijonen, H.; Komppula, R. 2007. Perception of success and its effect on small firm performance, Journal of Small Business and Enterprise Development 14(4): 689-701.

http://dx.doi.org/10.1108/14626000710832776

Sibińska, A. 2001. Zachowania marketingowe małych i średnich firm a styl kierowania ich właścicieli, Przeglą Organizacji 4: 39-41.

Smith, N. R. 1967. The Entrepreneur and his Firm: the Relationship between Type of Man and Type of Company. Michigan State University Press, East Lansing.

Stanworth, M. J.; Curran, J. 1976. Growth and the smaller firm - an alternative view, Journal of Management Studies May: 95-110. http://dx.doi.org/10.1111/j.1467-6486.1976.tb00527.x

Tang, Z. P.; Kreiser, M.; Marino, L.; Weaver, K. M. 2010. Exploring proactivness as a moderator in the process of perceiving industrial munificence: a field study of SMEs in four countries, Journal of Small Business Management 48(2): 97-115.

http://dx.doi.org/10.1111/j.1540-627X.2010.00288.x 
Todorov, O. 2008. The role of small and medium enterprises in world economies - some aspects, Economic Thought 4: 69-79.

Wijewardena, H.; Nanayakkara, G.; De Zoysa, A. 2008. The owner/manager's mentality and the financial performance of SMEs, Journal of Small Business and Enterprise Development 15(1): 150-161. http://dx.doi.org/10.1108/14626000810850892

Wilmańska, A. 2010. Raport o stanie sektora matych i średnich przedsiębiorstw $w$ Polsce $w$ latach 2008-2009 [Report about small and medium enterprises in Poland in 2008-2009]. PARP, Warszawa, Poland.

Wincent, J. 2005. Does size matter? A study of firm behavior and outcomes in strategic SME networks, Journal of Small Business and Enterprise Development 12(3): 437.

http://dx.doi.org/10.1108/14626000510612330

Xie, X. M.; Tam, C. M.; Wan, T. W. 2009. Relationships between business factors and performance in internationalization. An empirical study, China Management Decision 47(2): 308-329. http://dx.doi.org/10.1108/00251740910938939

Żołnierski, A.; Zadura-Lichota, P. 2008. Raport o stanie sektora matych i średnich przedsiębiorstw $w$ Polsce $w$ latach 2006-2007 [Report about small and medium enterprises in Poland in 2006-2007]. PARP, Warszawa, Poland, 26.

Zoysa, A.; Hearth, S. K. 2007. The impact of owner/managers' mentality on financial performance of SMEs in Japan an empirical investigation, Journal of Management Development 26(7): 652-666. http://dx.doi.org/10.1108/02621710710761289

Izabella STEINEROWSKA-STREB. Ph.D., is a lecturer at University of Economics in Katowice, Poland, in the Department of Economics and Policy Transformation. She is the author over 60 individually published papers, both in Polish and foreign scientific periodicals. Her research refers to the problems associated with small and medium enterprises and franchising chains. 